\title{
Characterization of the Diffusion of Organic Fungicides with Amine Oxides in White Pine and White Spruce
}

\author{
Simon Pepin,* Pierre Blanchet, and Véronic Landry \\ Wood products, especially those used in outdoor conditions, can be \\ damaged by dimensional changes and decay fungi. It is therefore advised \\ to use impregnation treatments to mitigate these hazards. While the \\ potency of the chemicals employed in the treatments is important, \\ characterization of the treatments is also crucial to ensure deep and \\ durable protection. In this study, eastern white pine (Pinus strobus L.) and \\ white spruce (Picea glauca (Moench) Voss) were impregnated with \\ propiconazole and 3-iodo-2-propynyl butylcarbamate (IPBC) through \\ diffusion. Instead of using pressure treatments, the samples were dipped \\ in solutions containing amine oxides, which can diffuse into the wood. The \\ treatments were characterized by the mass of fungicide impregnated, \\ fungicide leaching, and the impregnation depths of both the fungicides and \\ the amine oxides. It was found that the treatment impregnated slightly \\ more than $0.040 \mathrm{~kg} / \mathrm{m}^{3}$ of both fungicides, meeting EU standards. It was \\ also shown that the presence of amine oxides slightly prevented the \\ leaching of the fungicides in white pine. The penetration of the amine \\ oxides was several millimeters deep in all directions, but the penetrations \\ of the fungicides were much shorter and only longitudinal.
}

Keywords: Wood preservation; Amine oxides; Propiconazole; 3-Iodo-2-propynyl N-butylcarbamate;

Leaching; Impregnation; White pine; White spruce

Contact information: Department of Forest and Wood Sciences, Université Laval, G1V 0A6, 2325 Rue de l'Université, Québec, QC, Canada; *Corresponding author: Simon.pepin.1 @ulaval.ca

\section{INTRODUCTION}

Wood is a remarkable building material. However, some adverse agents and conditions, such as decay fungi, insects, ultraviolet rays, and dimensional changes due to humidity variations, can degrade it (Hill 2006). While good building designs can inhibit the damage from these agents, wood treatments can help to further improve its durability.

Wood, particularly when exposed to outdoor conditions, will be degraded by decay fungi and subjected to dimensional changes. These problems can be even worse if the wood is in contact with the ground, which greatly increases its moisture content (Siau 1995). Decay fungi feed on the wood's polymers, affecting its physical, chemical, and mechanical properties (Blanchette 1984; Blanchette et al. 1990; Goodell 2003; Brischke et al. 2019). They also can change the color of the decayed wood and sometimes cause cracks (Reinprecht 2016). Cyclic swelling and shrinkage of the wood with variations of its moisture content will eventually cause it to warp and crack and can lead to the failing of paints (Bonura et al. 2004; Glass and Zelinka 2010).

Both of these problems can be controlled with impregnation. Wood can be impregnated with a wide variety of inorganic and organic fungicides, including borates, carbamates, triazoles, copper oxides and carbonates, and quaternary compounds, to improve its resistance against decay fungi (Schultz and Nicholas 2003; Laks 2008; Ross 
2008). It can also be impregnated with different chemicals to increase its dimensional stability, such as resins (phenolic, amino, and silane) that bulk the lumen to block the entry of liquid water (Kocaefe et al. 2015; Reinprecht 2016). Different chemicals, including formaldehyde, anhydrides, epoxides, and 1,3-dimethylol-4,5-dihydroxyethyleneurea (DMDHEU), can also be used to crosslink the cell walls or modify wood's chemical nature. These treatments limit the capacity of the modified wood to swell and shrink, or they can increase its hydrophobicity (Wang and Piao 2011; Yuan et al. 2013). In addition to the nature of the chemicals, some other important factors when characterizing the effectiveness of a wood treatment are the amount of chemicals retained, their resistance to leaching, and the depth of their impregnation (Ibach 1999; Jiang 2008). These factors are influenced by the permeability of the wood, which is different for each species. The permeability is affected by the chemical, anatomical, and physical properties of the said species.

Wood is composed of three polymeric materials: cellulose, hemicelluloses, and lignins. Cellulose and hemicelluloses, the latter divided between the galactoglucomannans and the arabinoglucuronoxylans, are polysaccharides, which represent approximately $37 \%$ to $50 \%, 11 \%$ to $20 \%$, and $3 \%$ to $14 \%$ of the softwood's dry mass, respectively (Sjöström and Westermark 1999; Hill 2006; Stevanovic 2016). These components are very polar and contain many free hydroxyl groups that can bind to water through hydrogen bonds, increasing the wood's hygroscopicity. Lignins are complex tridimensional polymers made of different phenylpropane units and represent $25 \%$ to $37 \%$ of the mass of softwoods (Sjöström and Westermark 1999; Brown et al. 2003). Lignins are less polar than cellulose and hemicellulose, reducing the hydrophilicity of wood (Panshin et al. 1964). The extractives are a wide variety of smaller, non-structural compounds that can be found in both the lumen and the cell wall, where they may obstruct the flow of liquids and gases (Panshin et al. 1964; Sjöström 1993).

Wood permeability is affected by its anatomy, which varies greatly among different species. In softwoods, the longitudinal tracheids undertake both the support of the tree and the axial flow of liquids. These cells, composing $90 \%$ to $95 \%$ of the wood's volume, are oriented along the length of the stem (Havimo et al. 2008; Reinprecht 2016). The parenchyma rays, living cells oriented radially, are usually uniseriate and, in some species, bordered at the top and bottom by ray tracheids (Sjöström 1993; Wiedenhoeft 2010). The wood cells are connected through pits, small voids in the cell wall, which allow for gas and liquid exchange (Stamm 1967; Kuroda and Siau 1988). The pits connecting two tracheids have a semi-permeable layer called a torus, which can become aspired during drying and block the exchanges of gas and liquids (Petty and Puritch 1970; van Meel et al. 2011). Most of the tracheid pits are oriented on the radial cell walls. The rays also have pits, which can be of different shapes and sizes depending on the tree species (Wiedenhoeft 2010).

Different physical aspects influence the flow of liquids and gases into the wood. A high moisture content (MC) is needed to promote the opening of the cell pits. Their diameters can vary between $0.3 \mathrm{~nm}$ and $60 \mathrm{~nm}$, depending on the $\mathrm{MC}$ of the wood (Siau 1995). The diffusion of moisture into the lumen (intergas diffusion) increases with the temperature but decreases with the wood moisture content (Siau 1995; Baronas et al. 2001). It is much faster along the grain than perpendicularly, but the difference decreases when the MC increases. Diffusion of moisture through the cell wall is negligible at low MC, but it increases with the temperature and MC (Siau 1995). The flow of liquids is greatly affected by the sizes of the cells, as the permeability depends on the fourth power of the radius of the cell $\left(r^{4}\right)$ (Siau 1984). Non-linear flow causes energy losses when the diameter of the conduit changes, as with pits and cell wall curves, reducing the flow rate. 
Depending on the permeability of the species and the dimensions of the wood piece, different methods can be used for impregnation. For thin and permeable samples, simple methods such as dipping, spraying, and painting allow the introduction of chemicals into the wood with little equipment and at very low cost, but only to a limited depth (Lehringer et al. 2009; Schubert et al. 2011). By extending the dip to a few days or weeks (maceration), a deeper impregnation can be achieved. However, for larger pieces and difficult-to-treat species, autoclaves are often required. They allow different methods (Bethell, Rueping, modified full-cell, vacuum, etc.) to impregnate more deeply, using vacuum and/or high pressures (Ibach 1999; Leightley 2003; Freeman 2008). Wood can be pre-treated with methods including incising, microwaving, and chemical degradation to improve its permeability (Islam et al. 2008; Torgovnikov and Vinden 2010; Reinprecht 2016).

Recently, an aqueous wood preservation treatment was developed to allow deeper impregnation than the simple methods, without using an autoclave (Morris et al. 2014; Ross and Cutler 2015). Instead, it uses water-soluble tertiary amine N-oxides, which have the ability to diffuse into wood. Amine oxides (AOs) allow the solubilisation of organic compounds, like pesticides, in the solution, as well as their transportation into the wood (Walker and Shen 2002). They have antiseptic properties, improve the dimensional stability of the treated wood, and are resistant to leaching, as they become fixed to the acidic groups of the wood constituents (Tseng and Walker 2000; Tseng et al. 2002; Jiang 2008; Pepin et al. 2019). To avoid premature fixation of the AOs and ensure deep penetration, the treatment solution should be buffered to a slightly alkaline $\mathrm{pH}$, preferably with a borate buffer (Ross and Cutler 2015). Moreover, the AOs have very low toxicity to both humans and the environment (Sanderson et al. 2006, 2009). Despite their many attractive features, few studies have been published on these kinds of treatments.

This study characterized a wood treatment using an aqueous buffered AO delivery system to impregnate wood with organic fungicides through diffusion. A factorial design was used to understand how different elements of the treatment influenced its effectiveness. The factors studied were the AOs, the fungicides, and the time periods allotted for the diffusion. The aspects characterized were the depth of impregnation (for both the AOs and the fungicides), the amount of fungicides retained, and their resistance to leaching through immersion in deionized water. The depth of impregnation was measured by optical methods, and the masses of fungicides acquired during the impregnation and lost through leaching were quantified by liquid chromatography. This study followed the previous work of Pepin et al. (2019), which described the treatment's performances against fungal degradation and dimensional changes.

\section{EXPERIMENTAL}

\section{Materials}

Samples of eastern white pine (Pinus strobus L.) and white spruce (Picea glauca (Moench) Voss) were cut and stored in a conditioning room at $20{ }^{\circ} \mathrm{C} \pm 2{ }^{\circ} \mathrm{C}$ and $65 \% \pm 5 \%$ relative humidity $(\mathrm{RH})$, keeping them at an $\mathrm{MC}$ of $12 \%$. The samples for the leaching and extraction tests were $20 \mathrm{~mm} \times 20 \mathrm{~mm} \times 10 \mathrm{~mm}$ (longitudinal $\times$ tangential $\times$ radial). The samples for the penetration tests were $30 \mathrm{~mm} \times 30 \mathrm{~mm} \times 30 \mathrm{~mm}$, with growth ring angles of less than $10^{\circ}$ along the tangential direction. The white pine samples contained only sapwood, while the white spruce could have contained some heartwood, as its sapwood is very thin. All the samples were free of knots and visible stains. 
The N,N-dimethyldodecylamine N-oxide (approximately $30 \%$ aqueous solution), 3-iodo-2-propynyl N-butylcarbamate (97\%; IPBC), propiconazole (analytical standard grade), and indigo dye (synthetic; 95\%) were purchased from Sigma-Aldrich Co. (St. Louis, MO, USA). The American Chemical Society (ACS)-grade ortho-boric acid was obtained from Anachemia (Mississauga, Canada). Sodium tetraborate (98\%), petroleum ether (ACS-grade), and high-performance liquid chromatography (HPLC)-grade acetonitrile were purchased from Thermo Fisher Scientific (Ottawa, Canada). Propiconazole (Tilt 250E, 25\% aqueous solution) was generously supplied by Syngenta (Plattsville, Canada). The N,N-dimethylhexadecylamine $\mathrm{N}$-oxide was prepared as described in Pepin et al. (2019) and diluted into a 30\% aqueous solution.

\section{Methods}

\section{Wood treatment}

The wood samples were treated using a method inspired by Ward and Scott (2009) and Morris et al. (2014). The samples, freshly taken out of the conditioning room, were dipped in different hot $\left(65^{\circ} \mathrm{C}\right)$ treatment solutions for $15 \mathrm{~s}$, and sealed in plastic wraps for $6 \mathrm{~h}$ to avoid evaporation. The plastic wraps were removed, and the samples were set in a conditioning chamber for various durations to promote the diffusion of the chemicals. They were then left in the laboratory for one week to reduce their MC to less than $12 \%$ and avoid hysteresis, and they were placed back into the conditioning room until constant mass was achieved to restore them to their initial MC.

\section{Treatment and treatment solutions}

Several aqueous solutions were formulated for each test. These solutions were prepared with different conditions of AOs and fungicides. The solutions containing AOs were buffered with a borate buffer. The AOs used were dimethyldodecylamine oxide (DDAO) and dimethylhexadecylamine oxide (DHAO). The fungicides used were propiconazole and IPBC. The depth of impregnation of the fungicides was estimated using an indigo blue dye.

The solutions would usually contain $2.50 \mathrm{~g}$ of borate buffer (1.25 $\mathrm{g}$ of both orthoboric acid and sodium tetraborate) and $33.33 \mathrm{~g}$ of $30 \% \mathrm{AO}$ solutions (10 g of AOs), or no buffer and AO. However, to measure the penetration of the AOs, greater concentrations were needed, so $166.66 \mathrm{~g}$ of the AO solutions (50 g of AOs) was used instead. Additionally, the solutions could contain $2.50 \mathrm{~g}$ of IPBC, $1.00 \mathrm{~g}$ of propiconazole, or $2.50 \mathrm{~g}$ of indigo. Deionized water was then added to bring the total mass of the solutions to $500 \mathrm{~g}$. The concentrations of the chemicals in the different treatment solutions are listed in Table 1.

Table 1. Concentrations of the Chemicals in the Treatment Solutions

\begin{tabular}{|c|c|}
\hline Ingredient & Concentration (wt\%) \\
\hline Borate buffer & 0.5 \\
\hline AO & 2.0 (leaching, extraction, and dye penetration tests) \\
10 (amine oxide penetration tests)
\end{tabular}

Samples treated with these solutions were placed in a conditioning chamber $\left(85^{\circ} \mathrm{C}\right.$ $\left.\pm 1{ }^{\circ} \mathrm{C}, 85 \% \pm 3 \% \mathrm{RH}\right)$ for various durations to promote the diffusion of the chemicals. 
The combination of a treatment solution and a conditioning duration constituted a treatment. The treatments used for the different tests are given in Tables 2, 5, and 6, in their respective sections.

\section{Leaching}

The leaching of the fungicides was evaluated with a method based on AWPA E1112 (2012). Table 2 shows the different treatments used for this test. For each treatment and wood species, 12 samples were treated and separated into four sets of three samples. Essoua et al. (2015) suggested a water/wood volume ratio of 5, so these sets were placed in 150$\mathrm{mL}$ beakers with $60 \mathrm{~mL}$ of deionized water $\left(20^{\circ} \mathrm{C} \pm 2{ }^{\circ} \mathrm{C}\right)$. The beakers were installed onto an orbital agitator (Lab-Line, VWR, Mississauga, Canada) spinning at $100 \mathrm{rpm}$ for $14 \mathrm{~d}$. To avoid saturation of the water and to monitor the rate of leaching, within a reasonable number of analyses, the water was replaced after 6 h, 4 d, 9 d, and 14 d. Each time, the beaker was rinsed twice with a wash bottle of deionized water, which was added to the leachate. The fungicides were isolated through liquid-liquid extractions with $3 \times 15 \mathrm{~mL}$ of petroleum ether. The fractions of ether were combined and evaporated, and the fungicides were dissolved in $1.6 \mathrm{~mL}(2 \times 0.8 \mathrm{~mL}$, combined $)$ of acetone for HPLC analysis. The wood samples were then extracted to quantify the remaining fungicides.

\section{Soxhlet extractions}

Table 2. Conditions of the Treatments for the Leaching and Extraction Tests

\begin{tabular}{|c|c|c|c|}
\hline $\mathrm{AO}$ & Fungicide & $\begin{array}{l}\text { Conditioning Duration } \\
\text { (h) }\end{array}$ & Treatment ID* \\
\hline \multirow{2}{*}{ No AO/buffer } & IPBC & 24 & 01241 \\
\hline & Propiconazole & 24 & 0P241 \\
\hline \multirow{8}{*}{ DDAO + buffer } & \multirow{4}{*}{ IPBC } & 0 & $110^{2}$ \\
\hline & & 12 & $1112^{2}$ \\
\hline & & 24 & $1124^{1,2}$ \\
\hline & & 48 & $1148^{2}$ \\
\hline & \multirow{4}{*}{ Propiconazole } & 0 & $1 \mathrm{PO}^{2}$ \\
\hline & & 12 & $1 \mathrm{P} 12^{2}$ \\
\hline & & 24 & $1 \mathrm{P} 24^{1,2}$ \\
\hline & & 48 & $1 \mathrm{P} 48^{2}$ \\
\hline \multirow{8}{*}{$\begin{array}{c}1 \text { DDAO : } 3 \text { DHAO + } \\
\text { buffer }\end{array}$} & \multirow{4}{*}{ IPBC } & 0 & $210^{2}$ \\
\hline & & 12 & $2 \mid 12^{2}$ \\
\hline & & 24 & $2124^{1,2}$ \\
\hline & & 48 & $2148^{2}$ \\
\hline & \multirow{4}{*}{ Propiconazole } & 0 & $2 \mathrm{P} 0^{2}$ \\
\hline & & 12 & $2 \mathrm{P} 12^{2}$ \\
\hline & & 24 & $2 \mathrm{P} 24^{1,2}$ \\
\hline & & 48 & $2 \mathrm{P} 48^{2}$ \\
\hline \multicolumn{4}{|c|}{$\begin{array}{l}\text { * Treatment IDs are composed of the } A O \text { condition }(0=\text { no } A O, 1=D D A O+\text { buffer, } 2=1 \\
D D A O: 3 \text { DHAO + buffer }) \text {, the fungicide }(P=\text { propiconazole, I }=\text { IPBC }) \text {, and the } \\
\text { conditioning duration }(0=0 \mathrm{~h}, 12=12 \mathrm{~h}, 24=24 \mathrm{~h}, 48=48 \mathrm{~h}) . \\
1 \text { These treatments were included in the } \mathrm{AO} \times \text { fungicide factorial statistical analysis. } \\
2 \text { These treatments were included in the } \mathrm{AO} \times \text { conditioning duration and fungicide } \times \\
\text { conditioning duration factorial statistical analyses. }\end{array}$} \\
\hline
\end{tabular}

Prior to the extractions, the sample sets (approximately $4.5 \mathrm{~g}$ ) were ground into sawdust using a coffee grinder (SmartGrind, Black \& Decker, Towson, MD, USA). 
Approximately $1 \mathrm{~g}$ of sawdust was extracted for each sample set, and the results were extrapolated to the complete mass of the sets. Extractions were performed using a Soxhlet apparatus with $150 \mathrm{~mL}$ of acetone for $4 \mathrm{~h}$. After evaporation of the acetone, the wood extracts were washed with $5 \times 10 \mathrm{~mL}$ of petroleum ether. After evaporation of the petroleum ether, the isolated extracts were dissolved in $1.6 \mathrm{~mL}(2 \times 0.8 \mathrm{~mL}$, combined $)$ of acetone for HPLC analysis. The masses of fungicides obtained from the leaching and extraction experiments were added to obtain the amount of fungicides in the samples before the leaching.

HPLC

The isolated fungicides from the leaching experiment and Soxhlet extractions were quantified by HPLC using an Agilent 1100 series high-performance liquid chromatograph (Santa Clara, CA, USA) with a quaternary pump (model G13A) and an auto-sampler (model G1329A). The column was a Zorbax SB-C18 $5 \mu \mathrm{m}$, with dimensions of $4.6 \mathrm{~mm} \times$ $250 \mathrm{~mm}$. The detector was a UV-vis diode array detector (model G1315B). The methods for both fungicides were based on the works of Volkmer et al. (2010) and Miyauchi et al. (2005) and are described in Table 3. Each method was followed by a 5 minutes post run of $100 \%$ acetonitrile to remove the non-polar extractives from the column. In the case of the propiconazole, an additional $5 \mathrm{~min}$ of $100 \%$ deionized water was added to avoid any accumulation of phosphates.

Table 3. Method for the HPLC Analysis of the IPBC and Propiconazole

\begin{tabular}{|c|c|c|}
\hline \multirow{2}{*}{ Parameter } & \multicolumn{2}{|c|}{ Fungicide } \\
\cline { 2 - 3 } & IPBC & Propiconazole \\
\hline Injection volume & $20 \mu \mathrm{L}$ & $10 \mathrm{LL}$ \\
\hline Mobile phase & $50: 50$ acetonitrile $/$ water & $\begin{array}{c}60: 40 \text { acetonitrile } / 0.010 \mathrm{mM} \\
\text { phosphate buffer }\end{array}$ \\
\hline Flow rate & $0.9 \mathrm{~mL} / \mathrm{min}$ & $1.0 \mathrm{~mL} / \mathrm{min}$ \\
\hline Temperature & $60^{\circ} \mathrm{C}$ & $40^{\circ} \mathrm{C}$ \\
\hline Retention time & $8.1 \mathrm{~min}$ & $10.2 \mathrm{~min}$ and $10.4 \mathrm{~min}$ \\
\hline UV detection & $195 \mathrm{~nm}$ & $820 \mathrm{~nm}$ \\
\hline Bandwidth & $8 \mathrm{~nm}$ & $8 \mathrm{~nm}$ \\
\hline
\end{tabular}

For each analysis, the recovery percentage was studied, and the results were adjusted accordingly (Table 4). The recovery percentages of the liquid-liquid extractions were evaluated by adding $100 \mu \mathrm{L}$ of an acetone solution containing $1.00 \mathrm{mg} / \mathrm{mL}$ of fungicide to four 125-mL HDPE bottles with $65 \mathrm{~mL}$ of deionized water, which were extracted following the previously described procedure. The recovery percentages of the Soxhlet extractions were evaluated by adding $200 \mu \mathrm{L}$ of the same solution on each face of two $30 \mathrm{~mm} \times 30 \mathrm{~mm} \times 30 \mathrm{~mm}$ cubes for each species. From each cube, four fractions (1 g) were extracted following the described procedure. Using this method, the homogeneity of the sawdust was analysed at the same time as the recovery percentage.

Table 4. Recovery Percentages for the Liquid-liquid and Soxhlet Extractions

\begin{tabular}{|c|c|c|c|c|}
\hline \multirow{2}{*}{ Experiment } & \multicolumn{2}{|c|}{ IPBC } & \multicolumn{2}{|c|}{ Propiconazole } \\
\hline & White Pine & White Spruce & White Pine & White Spruce \\
\hline Liquid-liquid extraction & \multicolumn{2}{|c|}{$97 \%$} & \multicolumn{2}{|c|}{$99 \%$} \\
\hline Soxhlet extractions & $97 \%$ & $103 \%$ & $98 \%$ & $97 \%$ \\
\hline
\end{tabular}




\section{Impregnation depth}

The impregnation depths of both the AOs and the fungicides were monitored. In both cases, six samples of dimensions $30 \mathrm{~mm} \times 30 \mathrm{~mm} \times 30$ $\mathrm{mm}$ were treated for each treatment. The treated samples were cut with a band saw into $17 \mathrm{~mm} \times 17$ $\mathrm{mm} \times 17 \mathrm{~mm}$ cubes, from one of the corners. They were then reduced to $15 \mathrm{~mm} \times 15 \mathrm{~mm} \times 15 \mathrm{~mm}$ cubes with a table saw bench for smoother surfaces (Fig. 1). This method allowed for the observation of the penetration of the chemicals, from the surface of the initial cube to its center in all of the three principal planes. The impregnation depth was measured using an Olympus SZ61 stereo microscope (Tokyo, Japan) with 40× magnification and a micrometer (Velmex, Bloomfield, NY, USA) with a precision of $\pm 2 \mu \mathrm{m}$.

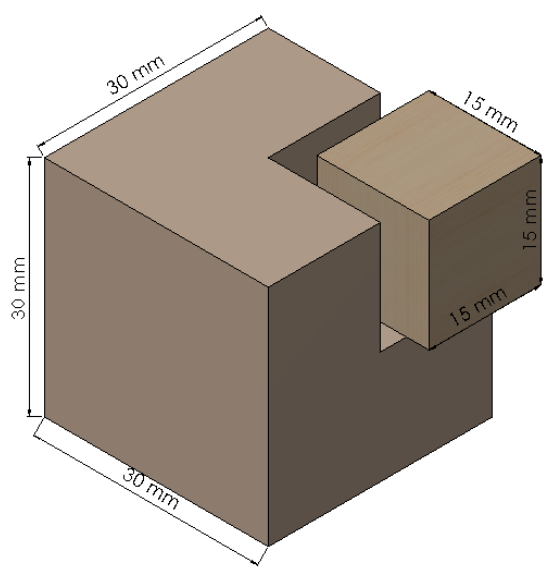

Fig 1. Dimensions of the treated sample and of the section selected for analysis

Table 5. Conditions of the Treatments for the AO Depth of Penetration Test

\begin{tabular}{|c|c|c|c|}
\hline $\mathrm{AO}$ & Fungicide & $\begin{array}{l}\text { Conditioning Duration } \\
\text { (h) }\end{array}$ & Treatment ID* \\
\hline \multirow{6}{*}{ DDAO + buffer } & \multirow{4}{*}{ No fungicide } & 0 & $1 \mathrm{NO}^{2}$ \\
\hline & & 12 & $1 \mathrm{~N} 12^{2}$ \\
\hline & & 24 & $1 \mathrm{~N} 24^{1,2}$ \\
\hline & & 48 & $1 \mathrm{~N} 48^{2}$ \\
\hline & IPBC & 24 & $1124^{1}$ \\
\hline & Propiconazole & 24 & 1P241 \\
\hline \multirow{12}{*}{$\begin{array}{c}1 \text { DDAO : } 3 \text { DHAO } \\
+ \text { buffer }\end{array}$} & \multirow{4}{*}{ No fungicide } & 0 & $2 \mathrm{NO}^{2,3,4}$ \\
\hline & & 12 & $2 \mathrm{~N} 12^{2,3,4}$ \\
\hline & & 24 & $2 \mathrm{~N} 24^{1,2,3,4}$ \\
\hline & & 48 & $2 \mathrm{~N} 48^{2,3,4}$ \\
\hline & \multirow{4}{*}{ IPBC } & 0 & $210^{3}$ \\
\hline & & 12 & $2112^{3}$ \\
\hline & & 24 & $2 \mathrm{I} 24^{1,3}$ \\
\hline & & 48 & $2148^{3}$ \\
\hline & \multirow{4}{*}{ Propiconazole } & 0 & $2 \mathrm{PO}^{3}$ \\
\hline & & 12 & $2 \mathrm{P} 12^{3}$ \\
\hline & & 24 & $2 \mathrm{P} 24^{1,3}$ \\
\hline & & 48 & $2 \mathrm{P} 48^{3}$ \\
\hline \multirow{4}{*}{$\begin{array}{c}1 \text { DDAO : } 3 \text { DHAO } \\
\text { no buffer }\end{array}$} & \multirow{4}{*}{ No fungicide } & 0 & $3 \mathrm{NO}^{4}$ \\
\hline & & 12 & $3 \mathrm{~N} 12^{4}$ \\
\hline & & 24 & $3 \mathrm{~N} 24^{4}$ \\
\hline & & 48 & $3 \mathrm{~N} 48^{4}$ \\
\hline \multicolumn{4}{|c|}{$\begin{array}{l}{ }^{*} \text { Treatment IDs are composed of the AO condition }(1=\mathrm{DDAO}+\text { buffer, } \\
2=1 \mathrm{DDAO}: 3 \mathrm{DHAO}+\text { buffer, } 3=1 \mathrm{DDAO}: 3 \mathrm{DHAO} \text { without buffer }) \text {, the fungicide }(\mathrm{N}= \\
\text { none, } \mathrm{P}=\text { propiconazole, I }=\mathrm{IPBC}) \text {, and the conditioning duration }(0=0 \mathrm{~h}, 12=12 \mathrm{~h}, 24= \\
24 \mathrm{~h}, 48=48 \mathrm{~h}) \text {. } \\
1 \text { These treatments were included in the } \mathrm{AO} \times \text { fungicide factorial statistical analysis; } \\
{ }^{2} \text { These treatments were included in the } \mathrm{AO} \times \text { conditioning duration factorial statistical } \\
\text { analysis; }{ }^{3} \text { These treatments were included in the fungicide } \times \text { conditioning duration } \\
\text { factorial statistical analysis. }{ }^{4} \text { These treatments were included in the buffer } \times \text { conditioning } \\
\text { duration factorial statistical analysis. }\end{array}$} \\
\hline
\end{tabular}


The longitudinal penetration was measured in the longitudinal-radial plane to examine the difference between the earlywood and latewood, while the radial and tangential penetrations were measured in the radial-tangential plane to allow their comparison on the same plane. Some treatments were also tested without the borate buffer. The treatments tested are shown in Tables 5 and 6.

Table 6. Conditions of the Treatments for the Indigo Blue Dye Depth of Penetration Test

\begin{tabular}{|c|c|c|c|}
\hline $\mathrm{AO}$ & Dye & $\begin{array}{l}\text { Conditioning Duration } \\
\text { (h) }\end{array}$ & Treatment ID* \\
\hline \multirow{4}{*}{ No AO/buffer } & \multirow{16}{*}{ Indigo blue } & 0 & OD0 ${ }^{1}$ \\
\hline & & 12 & $0 \mathrm{D} 12^{1}$ \\
\hline & & 24 & $0 \mathrm{D} 24^{1}$ \\
\hline & & 48 & $0 \mathrm{D} 48^{1}$ \\
\hline \multirow{4}{*}{ DDAO + buffer } & & 0 & $1 \mathrm{DO}^{1}$ \\
\hline & & 12 & $1 \mathrm{D} 12^{1}$ \\
\hline & & 24 & $1 \mathrm{D} 241$ \\
\hline & & 48 & $1 \mathrm{D} 48^{1}$ \\
\hline \multirow{4}{*}{$\begin{array}{c}1 \mathrm{DDAO}: 3 \mathrm{DHAO}+ \\
\text { buffer }\end{array}$} & & 0 & $2 \mathrm{D} 0^{1,2}$ \\
\hline & & 12 & $2 \mathrm{D} 12^{1,2}$ \\
\hline & & 24 & $2 \mathrm{D} 24^{1,2}$ \\
\hline & & 48 & $2 \mathrm{D} 48^{1,2}$ \\
\hline \multirow{4}{*}{$\begin{array}{c}1 \text { DDAO : } 3 \text { DHAO } \\
\text { no buffer }\end{array}$} & & 0 & $3 \mathrm{D} 0^{2}$ \\
\hline & & 12 & $3 \mathrm{D} 12^{2}$ \\
\hline & & 24 & $3 \mathrm{D} 24^{2}$ \\
\hline & & 48 & $3 \mathrm{D} 48^{2}$ \\
\hline \multicolumn{4}{|c|}{$\begin{array}{l}{ }^{*} \text { Treatment IDs are composed of the AO condition }(0=\text { no AO/buffer, } 1=\text { DDAO }+ \text { buffer } \\
2=1 \mathrm{DDAO}: 3 \mathrm{DHAO}+\text { buffer, } 3=1 \mathrm{DDAO}: 3 \mathrm{DHAO} \text { no buffer }) \text {, the dye (D), and the } \\
\text { conditioning duration }(0=0 \mathrm{~h}, 12=12 \mathrm{~h}, 24=24 \mathrm{~h}, 48=48 \mathrm{~h}) . \\
1 \text { These treatments were included in the } \mathrm{AO} \times \text { conditioning duration factorial statistical } \\
\text { analysis. } \\
2 \text { These treatments were included in the buffer } \times \text { conditioning duration factorial statistical } \\
\text { analysis. }\end{array}$} \\
\hline
\end{tabular}

As amine oxides are alkaline, it is possible to see them on the surface of wood by using a slightly acidic bromophenol blue solution. This $\mathrm{pH}$ indicator is yellow at low $\mathrm{pH}$ and blue at high $\mathrm{pH}$, making the amine oxides show up as a blue area on the yellow wood surfaces. The solution was prepared with $60.0 \mathrm{~g}$ of ethanol, $15.0 \mathrm{~g}$ of acetic acid, $0.3 \mathrm{~g}$ of bromophenol blue, and $225.0 \mathrm{~g}$ of water (Woo 2010). It was minutely applied on the wood surfaces with a foam brush to avoid any spreading of the AOs. It was noticed that wood treated with solutions containing $2 \%$ of AOs would not contain an adequate concentration of AOs to see enough coloration. Consequently, the solutions for this test used $10 \%$ of AOs instead.

To estimate the penetration of the fungicides, samples were treated with a solution containing an indigo blue dye rather than a fungicide. This particular dye was chosen because its chemical structure is closest to one of the fungicides used. Although this method prevents the study of any differences between the penetrations of the IPBC and the propiconazole, it gives an approximation of their distributions and impregnation depths, while allowing the use of a very direct and simple method of analysis. 


\section{Statistical analysis}

The treatments for the leaching, extraction, and $\mathrm{AO}$ penetration tests were selected to form three factorial designs: $\mathrm{AO} \times$ fungicide, $\mathrm{AO} \times$ conditioning duration, and fungicide $\times$ conditioning duration. The treatments used for each design are specified in their corresponding method section, and some of them could serve for more than one design. The treatments for the indigo penetration formed an $\mathrm{AO} \times$ conditioning duration factorial design, and the treatments without the borate buffer formed a buffer $\times$ conditioning duration factorial design. Analysis of variance (ANOVA) for these factorial designs was performed with the mixed procedure in the SAS University software (SAS, Cary, NC, USA) at an $\alpha$ of 0.05 . The effects of the factors were evaluated as significant $(\mathrm{p}<0.05)$ or very significant $(\mathrm{p}<0.01)$.

\section{RESULTS AND DISCUSSION}

\section{Leaching and Extractions}

The concentrations of fungicides present in the samples before the leaching experiment are shown in Table 7 . The results are reported in $\mathrm{kg} / \mathrm{m}^{3}$, which is a standard practice for impregnation treatments. However, because the impregnation depth test showed that the fungicides were not evenly distributed in the volumes of the samples, this notation was judged inaccurate, and the statistical analysis of the results will focus solely on the masses of the fungicides.

Table 7. Concentrations of IPBC and Propiconazole in the White Pine and White Spruce Samples before Leaching

\begin{tabular}{|c|c|c|c|c|c|}
\hline \multirow{2}{*}{$\mathrm{AO}$} & \multirow{2}{*}{ Fungicide } & \multirow{2}{*}{$\begin{array}{l}\text { Conditioning } \\
\text { Duration (h) }\end{array}$} & \multirow{2}{*}{ Treatment ID } & \multicolumn{2}{|c|}{ Concentration $\left(\mathrm{kg} / \mathrm{m}^{3}\right)$} \\
\hline & & & & White pine & White Spruce \\
\hline \multirow{2}{*}{$\begin{array}{c}\text { No } \\
\text { AO/buffer }\end{array}$} & IPBC & 24 & 0124 & 0.0489 & 0.0231 \\
\hline & Propiconazole & 24 & OP24 & 0.1163 & 0.0893 \\
\hline \multirow{8}{*}{$\begin{array}{c}\text { DDAO + } \\
\text { buffer }\end{array}$} & \multirow{4}{*}{ IPBC } & 0 & 110 & 0.1899 & 0.1186 \\
\hline & & 12 & 1112 & 0.0762 & 0.0458 \\
\hline & & 24 & 1124 & 0.0592 & 0.0158 \\
\hline & & 48 & 1148 & 0.0432 & 0.0190 \\
\hline & \multirow{4}{*}{ Prop. } & 0 & 1P0 & 0.1752 & 0.1242 \\
\hline & & 12 & $1 \mathrm{P} 12$ & 0.1367 & 0.1206 \\
\hline & & 24 & 1P24 & 0.1281 & 0.1029 \\
\hline & & 48 & $1 \mathrm{P} 48$ & 0.1139 & 0.0660 \\
\hline \multirow{8}{*}{$\begin{array}{c}1 \text { DDAO : } 3 \\
\text { DHAO } \\
+ \text { buffer }\end{array}$} & \multirow{4}{*}{ IPBC } & 0 & 210 & 0.2187 & 0.1096 \\
\hline & & 12 & $2 / 12$ & 0.0640 & 0.0264 \\
\hline & & 24 & 2124 & 0.0438 & 0.0190 \\
\hline & & 48 & 2148 & 0.0351 & 0.0185 \\
\hline & \multirow{4}{*}{ Prop. } & 0 & $2 \mathrm{PO}$ & 0.1887 & 0.1607 \\
\hline & & 12 & $2 \mathrm{P} 12$ & 0.1241 & 0.1373 \\
\hline & & 24 & $2 \mathrm{P} 24$ & 0.1097 & 0.1074 \\
\hline & & 48 & $2 \mathrm{P} 48$ & 0.1202 & 0.0816 \\
\hline
\end{tabular}

As expected, white pine was impregnated with more fungicides than white spruce. Anatomical features of the white pine, like its larger tracheids, its wider resin canals, its fenestriform pits (as opposed to piceoid of the white spruce), and its lower proportion of aspirated pits, make it overall more permeable to impregnation treatments (Panshin et al. 
1964; Olsson et al. 2001; Rhatigan et al. 2004). Interestingly, although this impregnation method does not allow as much control over the amount of chemicals impregnated as does pressure impregnation, the concentrations of fungicides were very similar to EU standards $\left(0.04 \mathrm{~kg} / \mathrm{m}^{3}\right.$ to $0.06 \mathrm{~kg} / \mathrm{m}^{3}$ for IPBC and $0.04 \mathrm{~kg} / \mathrm{m}^{3}$ to $0.12 \mathrm{~kg} / \mathrm{m}^{3}$ for propiconazole) (EC Directive 98/8/EC 2007; EC Directive 98/8/EC 2008).
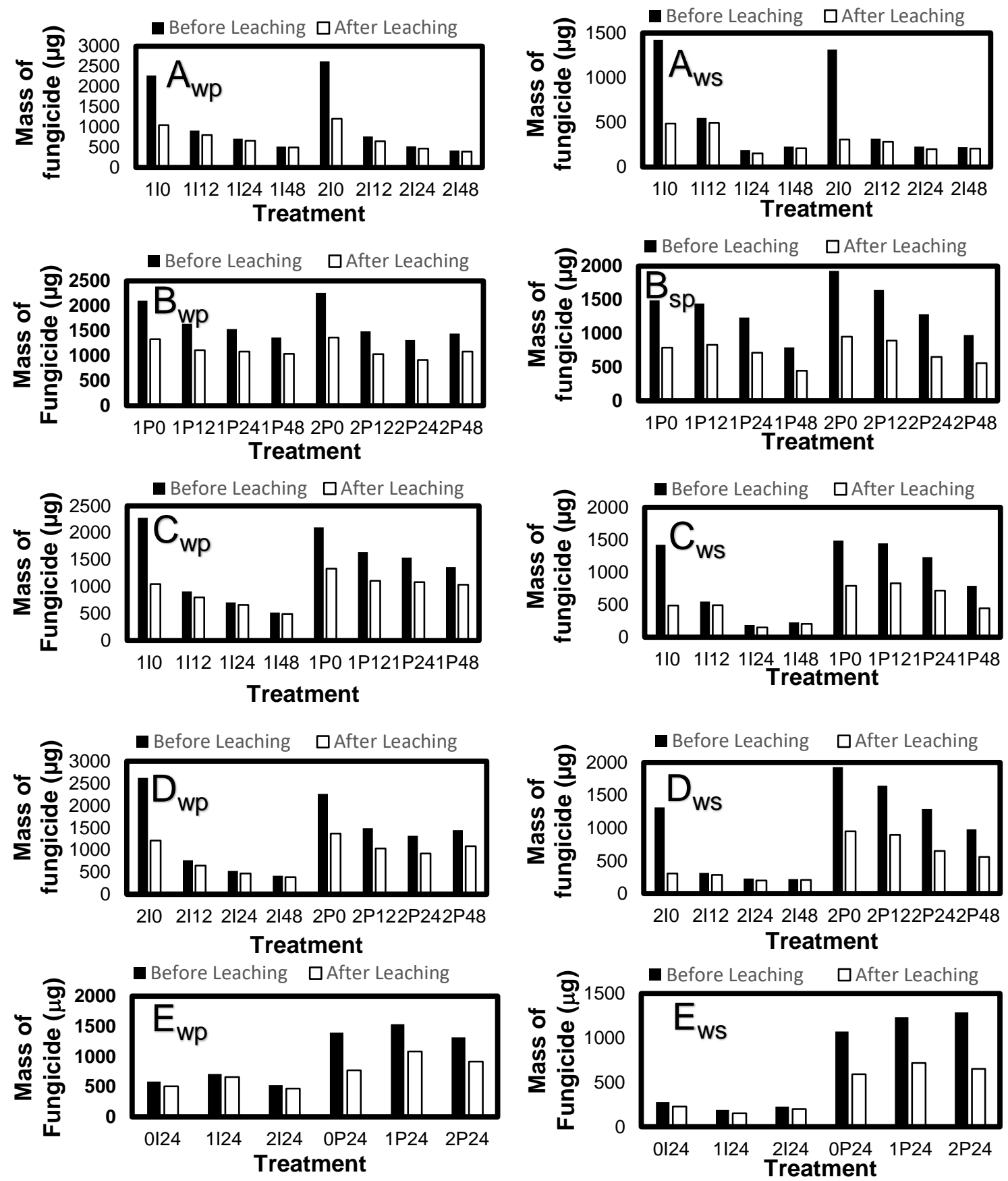

Fig. 2. Masses of IPBC and propiconazole before and after the leaching experiment, in white pine (wp, on the left) and white spruce (ws, on the right), following the factorial designs: (A) AO $\times$ conditioning duration (IPBC), (B) $A O \times$ conditioning duration (propiconazole), (C) fungicide $\times$ conditioning duration ( $\mathrm{AO}$ condition 1 ), (D) fungicide $\times$ conditioning duration (AO condition 2 ), and (E) $\mathrm{AO} \times$ fungicide 
The different statistical analyzes of the masses of the fungicides before and after leaching, for both species, are illustrated in Fig. 2 and showed that the conditioning duration was significant for both species and fungicides. Figures $2 \mathrm{~A}$ and $2 \mathrm{~B}$ show that the mass before leaching decreased with greater durations. This result indicates that some fungicides, probably not fixed to the wood components, were lost from the samples while they were in the conditioning chamber. This phenomenon was already suggested in a previous study, as biodegradation resistance to the brown-rot fungus $R$. placenta seemed to decrease with the conditioning duration (Pepin et al. 2019). This finding could be explained by the co-evaporation of IPBC and propiconazole, which is particularly important at a temperature above $55^{\circ} \mathrm{C}$ (Kukowski et al. 2017). Some losses could also be attributed to leaching from the condensation of water droplets in the conditioning chamber.

Lebow et al. (2004) reported that the leaching of preservatives begins rapidly with the loss of non-fixed chemicals and stabilizes when only the fixed preservatives remain. In this experiment, the amount of fungicides left in the wood after two weeks of leaching was stabilized at a lower level with the longer conditioning periods. This indicates that the mass of fungicides after leaching was not correlated to the mass of fungicides introduced by the dipping step of the treatment, but more likely to its mass just before the leaching. This suggests that some of the lost fungicides would eventually affix into the wood.

The fungicide $\times$ conditioning duration interaction was also very significant. As shown in Fig. 2C and 2D, while both fungicides had similar masses in samples not submitted to the conditioning chamber, they were affected by the conditioning duration divergently. The mass loss of IPBC was very rapid in the first $12 \mathrm{~h}$ of conditioning but then became more stable. For propiconazole, the mass loss was more linear over time, resulting in a greater mass at any given conditioning duration. This observation agrees with other workers, which showed that the loss of triazoles (like propiconazole) through evaporation and leaching is similar every week until stabilization (Woo 2010; Kukowski et al. 2017; Kukowski et al. 2018, 2019). Coors et al. (2014) also found that PBC, a degradation product of IPBC, leaches much faster than propiconazole. Kjellow et al. (2010) found that propiconazole passing through a chromatographic column of sawdust had greater retention than IPBC, which indicates stronger interactions with wood materials. This result could explain why IPBC leached more rapidly than propiconazole. The greater concentration of IPBC in the treatment solutions may also have distributed more non-fixated fungicides on the surfaces of the samples, which were immediately removed during the conditioning.

Surprisingly, the AOs did not significantly improve the masses of the fungicides before leaching (Fig. 2E), suggesting that they did not improve the absorption of fungicides. This finding was in contradiction with the impregnation depth results, which showed a deeper impregnation of the indigo dye in the presence of the AOs. These results could indicate that the fungicides did not penetrate the wood structure during the dipping, but only later. This way, the same amounts of fungicides (or indigo) are applied at the surfaces of the samples, which then penetrate the wood when AOs are present. However, the AOs were significant in white pine for the mass after leaching, as samples treated with AOs retained a greater amount of fungicides.

The statistical analysis of the leaching was performed by comparing the percentages of fungicides remaining in the samples after the experiment (Figs. 3 and 4). The leaching of the treatments without the conditioning chamber (1I0, 2I0, 1P0, and 2P0) give the best indication of the real leaching of the fungicides, as they exclude any preliminary loss caused by the conditioning. Kukowski et al. (2017) found that painted ponderosa pine with sealed ends, exposed for 6 months in Hawaii, lost only about $20 \%$ of its content in 
propiconazole. These results could however be considered in good agreement with the white pine studied in this publication, as leaching is reduced by the sealed longitudinal pathways which would otherwise be a main route for the loss of propiconazole (Haloni and Vergnaud 1997). The paint also reduces the leaching by slowing down the exchanges of water (Kukowski et al. 2018).

The fungicide $\times$ conditioning duration interaction was very significant for both AOs and species (Fig. 3B and 3C and Fig. 4B and 4C), with the IPBC exhibiting much less leaching than the propiconazole for all the conditioning durations except for the samples that were not conditioned. This result can be explained by recalling that a large amount of IPBC was lost in the conditioning chamber, while propiconazole was only slightly affected. Because of this phenomenon, most of the IPBC that would have been lost during the leaching test was already gone before the test had begun, which explains why the leaching was so low. In contrast, little propiconazole was lost in the conditioning chamber, so it leached more during the experiment.
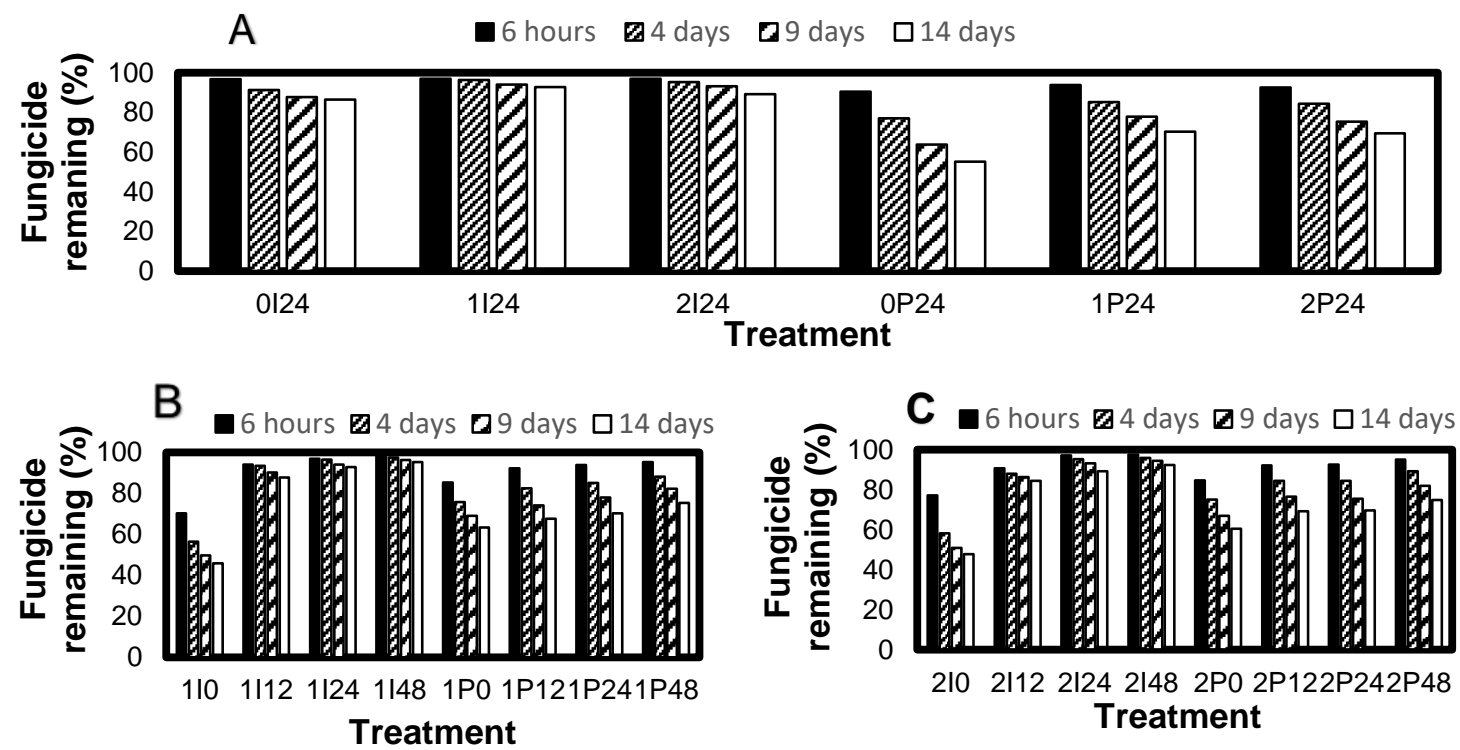

Fig. 3. Percentages of the remaining IPBC and propiconazole in white pine after $6 \mathrm{~h}, 4 \mathrm{~d}, 9 \mathrm{~d}$, and $14 \mathrm{~d}$ of leaching, following the factorial designs: $(A) A O \times$ fungicide, $(B)$ fungicide $\times$ conditioning duration ( $A O$ condition 1 ), and $(C)$ fungicide $\times$ conditioning duration ( $A O$ condition 2 )

The AOs were very significant for the white pine, with samples treated with AOs exhibiting the lowest leaching (Fig. 3A and 4A), but they were not significant for the white spruce. This result suggests that the penetration in the earlywood was not deep enough to reduce the leaching of the fungicides, while the deeper penetration in the latewood of the white pine helped to prevent some leaching. It would mean that the AOs themselves did not provide any leaching resistance.

It can be predicted that wood used in service would leach at a much slower pace than the results reported in this study. First, because flow is much greater axially, small samples with short longitudinal lengths and high proportions of end grain will leach substantially more than wood products with long longitudinal dimensions and a very low amount of end grain (Haloni and Vergnaud 1997). Also, wood in service is rarely immersed in water, while leaching tests by immersion tend to overestimate the actual leaching of chemicals in their real conditions of use (Lebow et al. 2004). 

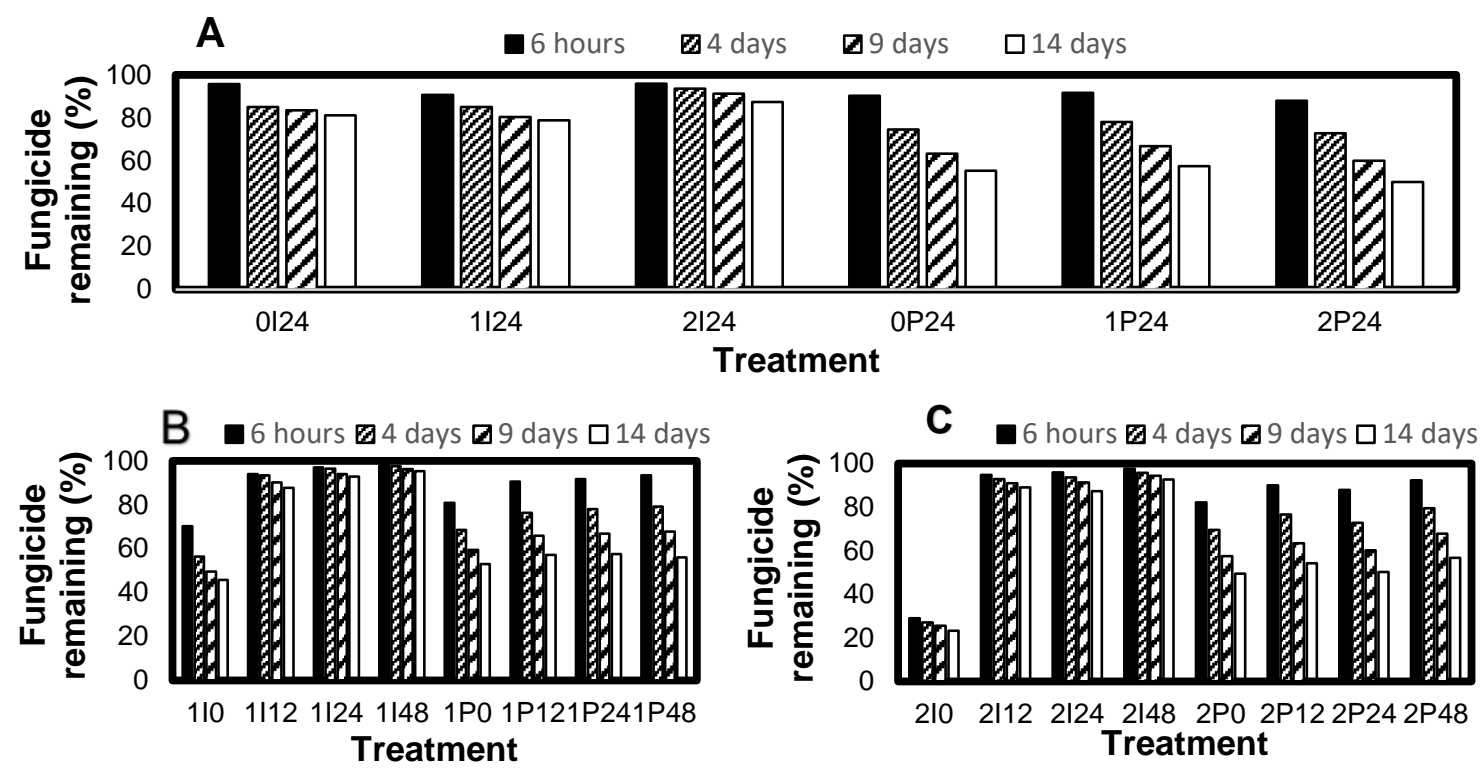

Fig. 4. Percentages of the remaining IPBC and propiconazole in white spruce after $6 \mathrm{~h}, 4 \mathrm{~d}, 9 \mathrm{~d}$, and $14 \mathrm{~d}$ of leaching, following the factorial designs: $(\mathrm{A}) \mathrm{AO} \times$ fungicide, $(\mathrm{B})$ fungicide $\times$ conditioning duration ( $\mathrm{AO}$ condition 1 ), and $(\mathrm{C})$ fungicide $\times$ conditioning duration (AO condition 2 )

A leaching experiment simulating rainfall would have yielded a better approximation of the leaching rate of a wood product used outdoors, but the large number of samples used in this study would have made it very complex.

\section{Depth of Impregnation}

The impregnation depths of the AOs, in the longitudinal, radial, and tangential axes (Figs. 5 and 6), was quite uniform on all the widths of the samples and showed no distinction between the earlywood and latewood.

Although white spruce is harder to treat (Olsson et al. 2001), the impregnation depths in all three axes were similar for both species. As expected, the impregnation was much deeper along the fiber than perpendicularly, and it was generally deeper in the radial axis than the tangential (Matsumura et al. 1998). This last point, however, is not always true in the case of white spruce. Radial permeability is strongly influenced by the presence of rays and ray tracheids (Olsson et al. 2001; Wan and Kim 2006). It is especially true during pressure impregnation, as such a process damages the cross-field pits and widens their openings (McQuire 1970). In this case, the thick cell walls and small piceoid pits of the white spruce rays, combined with the absence of pressure during the treatment, may have had a meaningful impact on the radial permeability.

Furthermore, the occurrence of aspirated pits in white spruce is very high (Usta 2005). In contrast, the rays of the white pine have much thinner cell walls and possess large pinoid pits, which are less aspirated, so their permeability is better. Samples treated with the borate buffer showed improved impregnation in all species and axes, except for the radial axis in the white spruce. 

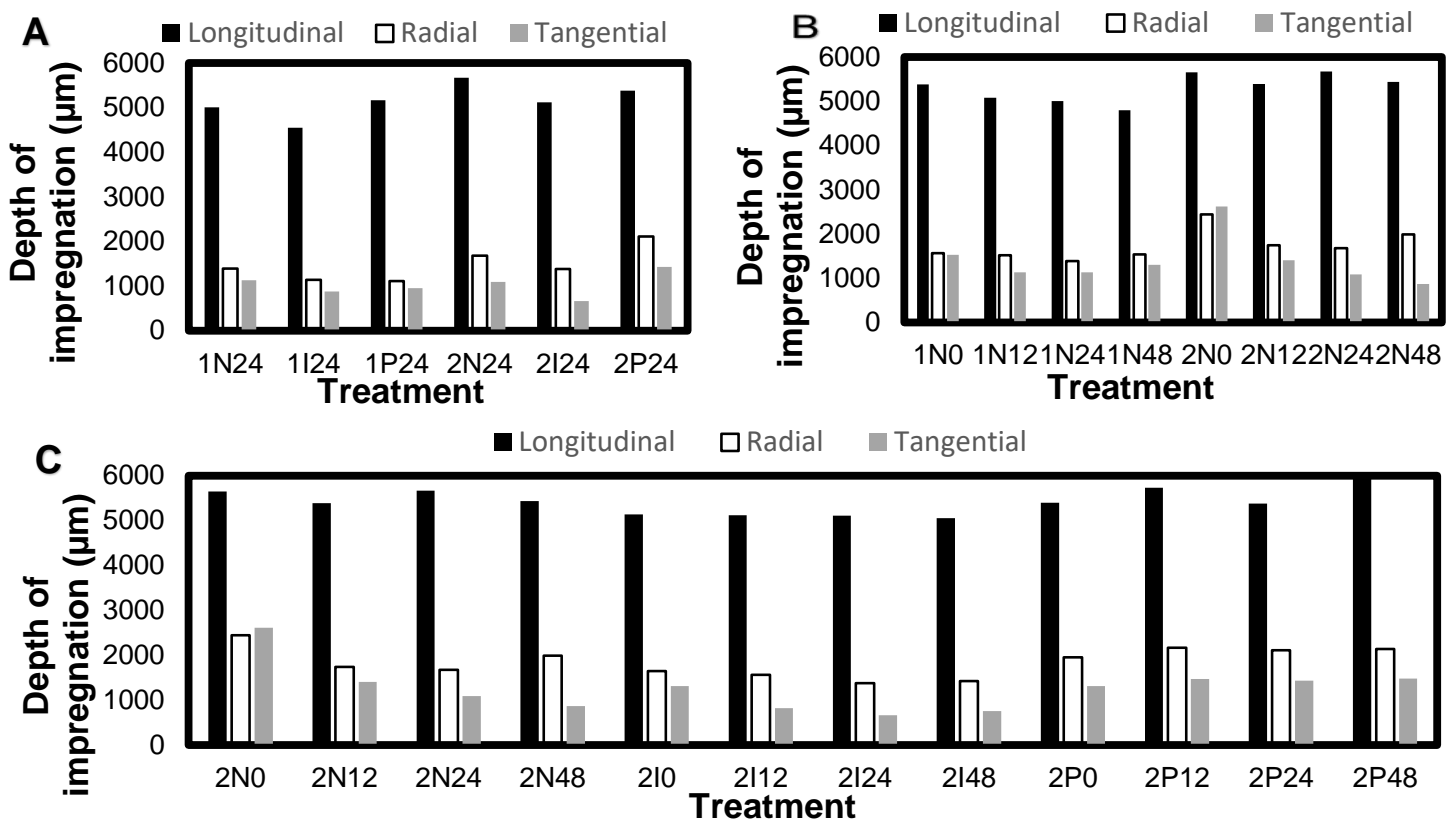

Fig. 5. Greatest impregnation depths of the AOs in white pine following the factorial designs: $(A)$ $\mathrm{AO} \times$ fungicide, $(\mathrm{B}) \mathrm{AO} \times$ conditioning duration, and $(\mathrm{C})$ fungicide $\times$ conditioning duration
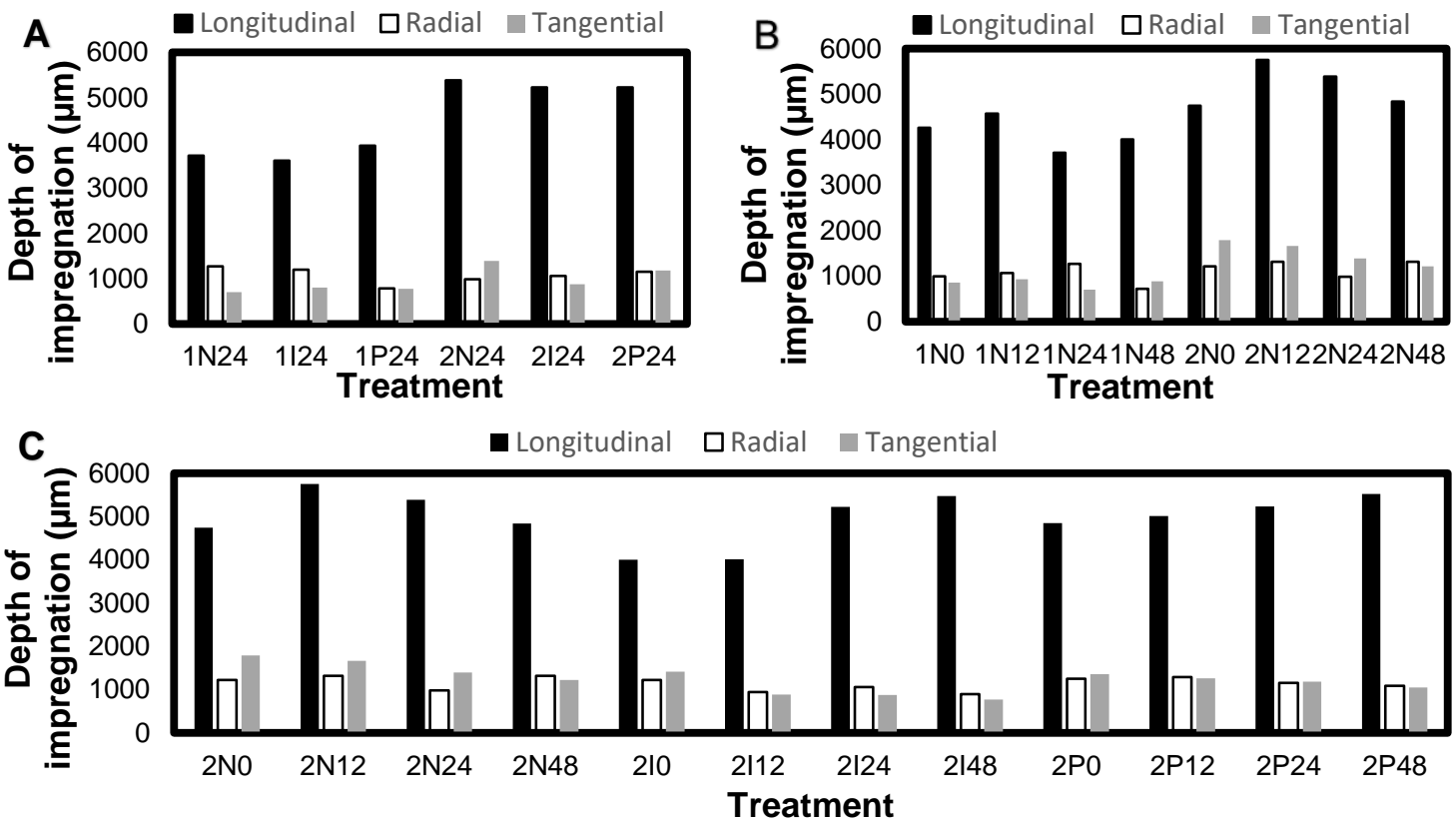

Fig. 6. Greatest impregnation depths of the AOs in white spruce following the factorial designs: (A) $\mathrm{AO} \times$ fungicide, $(\mathrm{B}) \mathrm{AO} \times$ conditioning duration, and (C) fungicide $\times$ conditioning duration

The statistical analysis of the greatest impregnation depths of the AOs showed the $\mathrm{AO}$ to be a very significant factor for both species and all three axes (Figs. 5A, 5B, 6A, and $6 \mathrm{~B}$ ). Surprisingly, the solutions containing DHAO exhibited the greatest penetrations, even though it is larger and heavier than DDAO. As the diffusion mechanisms of the AOs in wood are not described in the literature, the treatment solutions' penetrations were investigated instead. The Washburn equation states that the penetration of a liquid in a capillary increases with its surface tension and the cosine of the contact angle between the 
liquid and the capillary, but it decreases with its viscosity (de Meijer et al. 2001; Li et al. 2014). Table 8 shows these variables as obtained for solutions $1 \mathrm{~N}$ and $2 \mathrm{~N}$. According to these results, the treatment solutions without DHAO had the greatest liquid penetrations, indicating that the difference in impregnation depths cannot be attributed to capillarity, but more likely to diffusion. It can therefore be predicted that DHAO can diffuse more readily into wood than DDAO.

Table 8. Surface Tensions, Contact Angles on the Tangential-longitudinal Face of White Pine and White Spruce, and Viscosities of Solutions $1 \mathrm{~N}$ and $2 \mathrm{~N}$ at $65^{\circ} \mathrm{C}$

\begin{tabular}{|c|c|c|c|c|c|c|}
\hline \multirow[b]{2}{*}{ Solution } & \multirow{2}{*}{$\begin{array}{l}\text { Surface } \\
\text { Tension } \\
(\mathrm{mN} / \mathrm{m})\end{array}$} & \multicolumn{2}{|c|}{ Contact Angle $\left({ }^{\circ}\right)$} & \multicolumn{2}{|c|}{ Cosine of the Contact Angle } & \multirow[b]{2}{*}{$\begin{array}{c}\text { Viscosity } \\
\text { (cP) }\end{array}$} \\
\hline & & White Pine & $\begin{array}{l}\text { White } \\
\text { Spruce }\end{array}$ & White Pine & $\begin{array}{l}\text { White } \\
\text { Spruce }\end{array}$ & \\
\hline $1 \mathrm{~N}$ & 29.28 & 45.88 & 50.93 & 0.696 & 0.630 & 1.07 \\
\hline $2 \mathrm{~N}$ & 27.19 & 74.29 & 77.03 & 0.271 & 0.224 & 21.27 \\
\hline
\end{tabular}

The conditioning duration was not a significant factor for the longitudinal penetration of the AOs, but it was significant in the radial and tangential axes (Figs. 5C and 6C). The impregnation depth was almost always shorter as the conditioning duration increased. To explain this observation, one should remember that the leaching experiment showed that the chemicals were lost from the samples while they were in the conditioning chamber. Because the absorption of chemicals is much faster along the grain than perpendicularly, it can be concluded that most of the removed preservatives were on the longitudinal-radial and longitudinal-tangential faces of the samples, thus affecting the impregnation only in those directions. Because diffusion is primarily driven by a concentration gradient, it is obvious that removing AOs from the samples will reduce their penetrations. This observation also explains why the amount of fungicides after two weeks of leaching was affected by the conditioning chamber: It removed not only chemicals that would stay at the surface of the wood and leach easily but also chemicals that would eventually be absorbed and fixed. It is possible that a longer period is needed before placing the sample in the conditioning chamber to have better results, or that the conditioning chamber simply does not help to improve the diffusion.

Similarly, the fungicide was not a significant factor in the longitudinal axis, but it was significant in both the tangential and radial axes (Figs. 5C and 6C). The solutions with propiconazole and without fungicide usually exhibited very similar impregnation depths of the AOs, while the presence of IPBC always led to a large decrease. This result could suggest that there were some interactions between the wood, the fungicides, and the AOs carrying them, which would limit the diffusion of the latter. These interactions do not seem to be physical, as IPBC molecules are smaller and lighter than those of propiconazole. It is also unlikely that chemical interactions between the fungicides and the wood would impair the diffusion, as propiconazole has stronger interactions with wood than does IPBC (Kjellow et al. 2010). However, as the AOs micelles are larger when they contain fungicides than when they are empty (Oraedd et al. 1992), they may become unable to penetrate the narrow radial pits of the wood. The concentration of AOs in the wood would therefore be lower when used with fungicides, reducing their diffusion. It is possible that both fungicides should reduce the impregnation of AOs equivalently, but because the experiment used IPBC as a pure solid while propiconazole was used as a ready-to-use solution, some unknown additives from the formulation of the latter could improve the penetration of the treatment. Schubert et al. (2011) impregnated wood by dipping with 
different commercial IPBC formulations and observed different radial penetrations (from less than $500 \mu \mathrm{m}$ to more than $1000 \mu \mathrm{m}$ ), suggesting that formulations can influence the impregnation.

The presence of borates led to a very significant improvement of the impregnation of AOs in all axes for the white pine (Fig. 7). For the white spruce, it was also very significant in all three axes, though with a decreased radial impregnation depth.
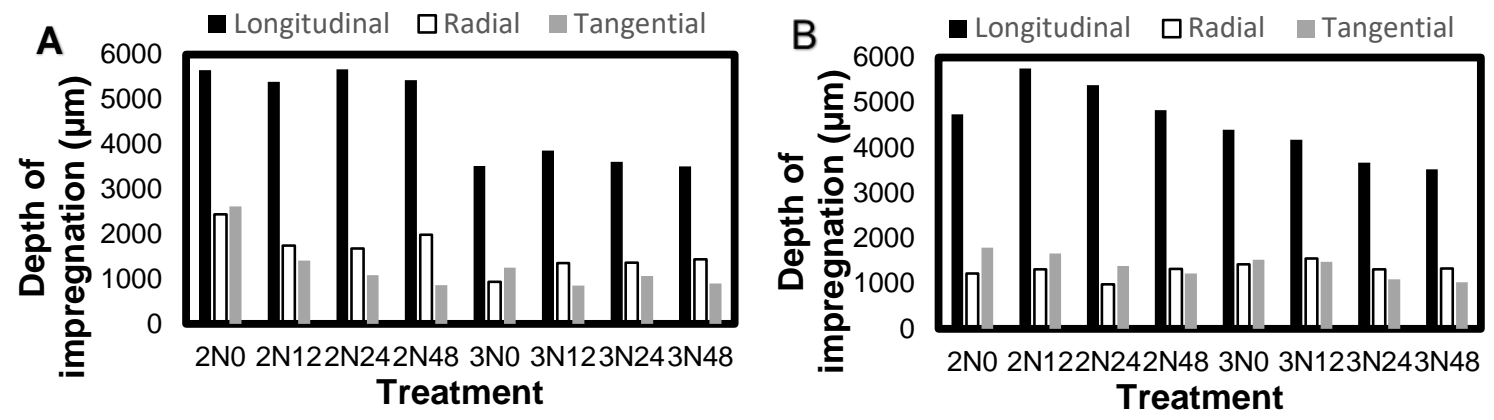

Fig. 7. Greatest impregnation depths of the AOs in (A) white pine and (B) white spruce, with $(2 \mathrm{N \# )}$ and without $(3 \mathrm{N \# )}$ borates

Solutions containing AOs exhibited superior solubilization of the indigo blue dye and showed very uniform coloration on all the faces of the treated samples. In contrast, the solution without AO exhibited poor solubilization of the dye, and the treated samples showed uneven coloration, as well as heaps of dye on some faces. The longitudinal penetration of the dye differed noticeably between the two species studied. The impregnation of the white pine was quite uniform in the earlywood and penetrated much deeper into the latewood, resulting in long and narrow peaks (Fig. 8). In the white spruce, the earlywood was also uniformly impregnated, but the latewood was not impregnated at all. The distribution in the white pine is common among softwoods and can be explained by two differences between the earlywood and the latewood: smaller lumens and thicker cell walls. While the smaller lumens decrease the permeability of the latewood, the thicker cell walls reduce its flexibility. This rigidity reduces non-linear flow and the frequency of the pits' aspiration, which improves the permeability (Petty and Puritch 1970; Siau 1995). In most softwood species, the latewood is more permeable than the earlywood (Siau 1984). However, Flynn (1995) reported that studies on the permeability of white spruce showed a wide variety of behaviours when comparing the relative permeabilities of its earlywood and latewood. In the present case, the size of the tracheids of the latewood might be responsible for its lack of permeability. The sizes of the latewood cells' lumens were examined with a microscope and measured to be, on average, only $14 \mu \mathrm{m} \times 19 \mu \mathrm{m}$ for the white spruce, compared to $23 \mu \mathrm{m} \times 37 \mu \mathrm{m}$ for the white pine. As a result, the density of the latewood was much greater in the white spruce than the white pine, with values measured by X-ray scanning (Quintek Measurement Systems, Knoxville, TN, USA) of $1179 \mathrm{~kg} / \mathrm{m}^{3}$ and $807 \mathrm{~kg} / \mathrm{m}^{3}$, respectively. Because this treatment does not use pressure to aid the impregnation, capillarity plays an important role in the penetration of the chemicals. Because capillarity is highly influenced by the radius of the capillary, the lumens of the white spruce's latewood might be too small to allow any impregnation without pressure. 


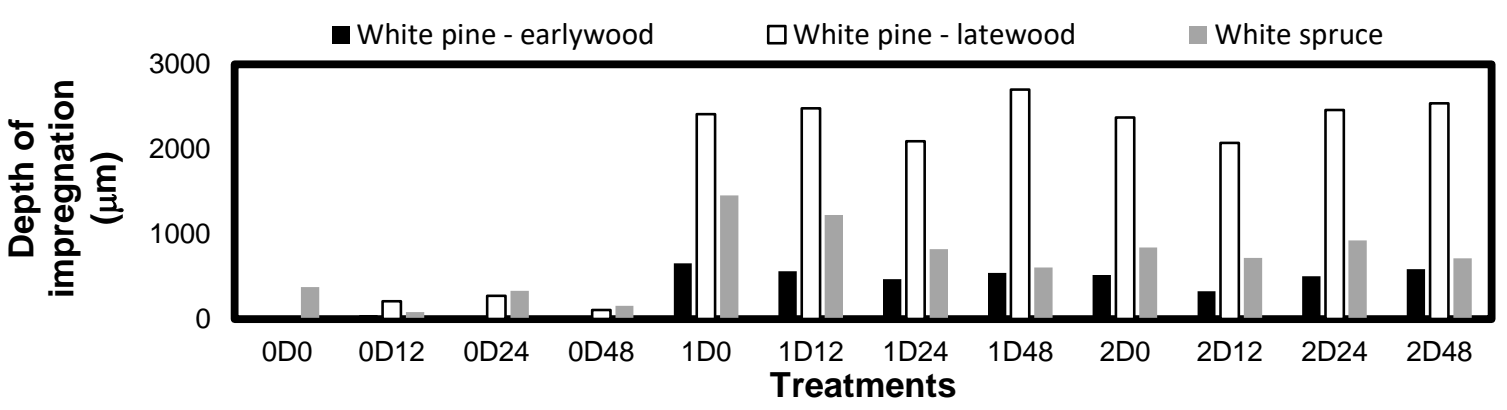

Fig. 8. Impregnation depths of the indigo dye in white pine and white spruce

Surprisingly, the penetration of the earlywood with the indigo blue dye was deeper in the white spruce than the white pine (Fig. 8). This result could be caused by the presence of air in the wood. Because of their smaller lumen, the cells of the latewood have a greater capillary force than those of the earlywood (Rydholm 1967). As a result, when the latewood is impregnated, the air is pushed from the latewood into the earlywood, which hinders its impregnation. Because the white spruce was only impregnated in the earlywood, the air could be pushed from the earlywood to the latewood instead, which eased its impregnation.

Only the white spruce showed impregnation without the use of AO. However, this impregnation was not uniform. Rather, it presented as one or few very localized (1 $\mathrm{mm}$ to $2 \mathrm{~mm}$ wide) section(s) on the samples. There was no evidence of penetration of the dye in the resin canals at this magnification, although they are usually impregnated by aqueous treatments (Siau 1984). The impregnation of the wood with the indigo dye showed no penetration in the radial and tangential axes, so wood preparation techniques such as incising could be considered to improve the radial protection (Schubert et al. 2011). Nonetheless, because the AOs do penetrate perpendicularly to the grain and have antiseptic properties (Pepin et al. 2019), the wood still receives some radial antifungal protection from the treatment. Moreover, the penetration of the AOs in white spruce is similar to the $0.8 \mathrm{~mm}$ to $3 \mathrm{~mm}$ impregnation obtained by other workers while using vacuum and pressure methods with different chemicals and spruce species (Messner et al. 2003; Gindl et al. 2004; Voulgaridis et al. 2015). In the case of white pine, however, over $40 \mathrm{~mm}$ of penetration can be achieved through pressure treatments (Scholz et al. 2010). This finding suggests that, when taking specific permeability into account, less permeable wood species are more suited to the diffusion of the AOs than permeable species. Jiang (2008) showed that combining pressure and amine oxides allowed a deep penetration in both southern yellow pine (permeable) and Douglas fir (impermeable). Samples treated with the borate buffer were impregnated far deeper than those treated with unbuffered solution (Fig. 9).

The statistical analysis of the impregnation depths of the indigo blue dye into the white pine (earlywood and latewood) and white spruce always showed a very significant effect of the AOs. Although white spruce showed some penetration even without AOs, Fig. 8 clearly shows their substantial impact on the impregnation depth. Both the earlywood and latewood of the white pine showed a significant effect for the borate buffer, while the effect was very significant for the white spruce (Fig. 9). The results tend to show that the distance traveled by the dye (and probably by a fungicide) is affected by the distance AOs are able to travel before becoming fixed to the wood. 


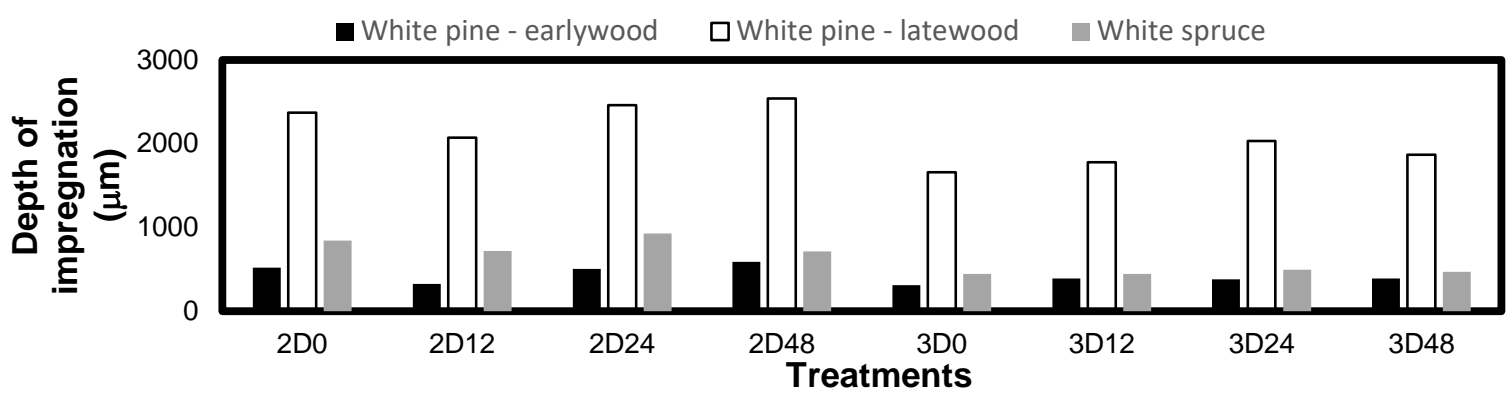

Fig. 9. Impregnation depths of the indigo dye in white pine and white spruce, with and without borates

Unlike what the literature seemed to suggest (Ward and Scott 2009; Morris et al. 2014), the results revealed that the impregnation of AOs and indigo dye was not related to the gas permeability of the wood. The diffusion of water vapor, particularly through the cell wall, is affected by both the temperature and the MC. It was thus expected that the high relative humidity and temperature in the conditioning chamber would improve the diffusion of water into the samples and promote the transportation of the treatment. However, it was noted that the only effect of the conditioning on the impregnation depth was a reduction in the penetration of the AOs in the radial and tangential axes. Nevertheless, a few aspects of the treatment could be investigated to promote its penetration, the first of which is the diffusion. As the diffusion is driven by a concentration gradient, an increase in the amount of chemicals (AOs) absorbed should deepen their diffusion. The concentration of the AOs in the solution could therefore be optimised to maximise their uptake. A second element to consider is the flow of the solution during the dipping. According to the Washburn equation, very few parameters can influence the flow of a solution into the wood, and those under the control of the experimenter are the viscosity of the solution, its surface tension, and its contact angle with the cell wall (de Meijer et al. 2001). For example, the lowest viscosity should be targeted to allow the fastest absorption of the solution. It can be reduced by increasing the temperature of the solution, by limiting the concentration of viscous chemicals, and by using co-solvents. Moreover, with greater flow, the solution can progress more deeply into the wood before the diffusion process even takes place. A longer dipping could also be considered to further increase the penetration of the solution and the uptake of chemicals. Those two last points would also increase the amount of water absorbed, which would increase the MC of the treated wood. Because a greater MC promotes the diffusion of borates (Caldeira 2010), it could be expected to promote the diffusion of AOs as well. Finally, the $\mathrm{pH}$ of the solution should be optimised to allow the deepest impregnation of the AOs before their fixation to the acidic groups of the wood.

\section{CONCLUSIONS}

1. The impregnation of wood with fungicides through the diffusion of AOs was demonstrated as possible. The AOs could diffuse quite deeply in the longitudinal, radial, and tangential axes, without requiring any pressure or vacuum. While the indigo dye did not penetrate the wood without AOs, they allowed a certain longitudinal 
impregnation. The AOs, however, did not seem to increase the amount of fungicides impregnated and their resistance to leaching.

2. It could not be established whether the mass of fungicides impregnated by the treatment was improved by the AOs. It was however shown that they could reduce their leaching in white pine. In contrast, it was clear that the conditioning of the wood samples following the dipping led to a large loss of chemicals. This loss was particularly quick for the IPBC, while it was slower and more linear for propiconazole. The opposite pattern was observed for the leaching experiment, where samples with less conditioning leached more, as they had more fungicides remaining on their surfaces. Both of the results, of the impregnation depth test and of the leaching test, suggested that the material lost during the conditioning would become partially affixed in the wood if it were not washed off.

3. Surprisingly, the treatments using DHAO impregnated deeper than those using only DDAO, although the former is larger. While the longitudinal impregnation of the AOs was similar for all treatments, the presence of fungicides or the use of the conditioning chamber reduced the radial and tangential penetrations. Unlike the AOs, the impregnation of the indigo blue dye was only longitudinal. It was greatly increased by the presence of AOs but not affected by their chemical structures. The buffering of the treatment solutions with borates greatly helped the penetrations of the AOs and the indigo dye.

\section{ACKNOWLEDGMENTS}

The authors are grateful to the Natural Sciences and Engineering Research Council of Canada (NSERC) for financial support through its IRC and CRD programs (IRCPJ 461745-18 and RDCPJ 524504-18), as well as the industrial partners of the NSERC Industrial Chair on Eco-responsible Wood Construction (CIRCERB).

\section{REFERENCES CITED}

AWPA E11-12 (2012). "Standard method for accelerated evaluation of preservative leaching," American Wood Protection Association, Birmingham, AL, USA.

Blanchette, R. A. (1984). "Screening wood decayed by white rot fungi for preferential lignin degradation," Applied and Environmental Microbiology 48(3), 647-653.

Blanchette, R. A., Nilsson, T., Daniel, G., and Abad, A. (1990). "Biological degradation of wood," in: Archaeological Wood, R. M. Rowell and R. J. Barbour (eds.), American Chemical Society, Washington, D.C., USA, pp. 141-174.

Baronas, R., Ivanauskas, F., Juodeikiene, I., and Kajalavicius, A. (2001). "Modelling of moisture movement in wood during outdoor storage," Nonlinear Analysis: Modelling and Control 6(2), 3-14. DOI: 10.15388/NA.2001.6.1.15210

Bonura, T., Bussjeager, S., Christensen, L., Daisey, G., Daniels, T., Hirsch, M., Jourdain, C. J., Mall, D. D., Springate, B., Wagner, L. E., et al. (2004). "Finishes checklist: A guide to achieving optimum coating performance on exterior wood surfaces," JCT CoatingsTech 1(3), 36-49. 
Brischke, C., Stricker, S., Meyer-Veltrup, L., and Emmerich, L. (2019). "Changes in sorption and electrical properties of wood caused by fungal decay," Wood Research and Technology 73(5), 445-455. DOI: 10.1515/hf-2018-0171

Brown, A. L., Hames, B. R., Daily, J. W., and Dayton, D. C. (2003). "Chemical analysis of solids and pyrolytic vapors from wildland trees," Energy \& Fuels 17(4), 10221027. DOI: $10.1021 /$ ef020229v

Caldeira, F. (2010). "Boron in wood preservation: A review in its physico-chemical aspects," Silva Lusitana 18(2), 179-196.

Coors, A., Weisbrod, B., Schoknecht, U., Sacher, F., and Kehrer, A. (2014). "Predicting acute and chronic effects of wood preservative products in Daphnia magna and Pseudokirchneriella subcapitata based on the concept of concentration addition," Environmental Toxicology and Chemistry 33(2), 382-393. DOI: 10.1002/etc.2431

de Meijer, M., Thurich, K., and Militz, H. (2001). "Quantitative measurements of capillary coating penetration in relation to wood and coating properties," Holz als Roh- und Werkstoff 59(1-2), 35-45. DOI: 10.1007/s001070050469

Essoua, G. G., Blanchet, P., Landry, V., and Beauregard, R. (2015). "Maleic anhydride treated wood: Effects of drying time and esterification temperature on properties," BioResources 10(4), 6830-6860. DOI: 10.15376/biores.10.4.6830-6860

European Commission (EC) Directive 98/8/EC (2007). "Directive 98/8/EC concerning the placing of biocidal products on the market - Inclusion of active substances in Annex I to directive 98/8/EC - Propiconazole," European Union, Finland.

European Commission (EC) Directive 98/8/EC (2008). “Directive 98/8/EC concerning the placing of biocidal products on the market - Inclusion of active substances in Annex I to directive 98/8/EC - IPBC," European Union, Denmark.

Flynn, K. A. (1995). "A review of the permeability, fluid flow, and anatomy of spruce (Picea spp.)," Wood and Fiber Science 27(3), 278-284.

Freeman, M. H. (2008). "Wood preservative formulation development and systems: Organic- and inorganic-based systems," in: Development of Commercial Wood Preservatives: Efficacy, Environmental, and Health Issues, T. P. Schultz, H. Militz, M. H. Freeman, B. Goodell, and D. D. Nicholas (eds.), American Chemical Society, Washington, D.C., USA, pp. 408-426. DOI: 10.1021/bk-2008-0982.ch024

Gindl, W., Hansmann, C., Gierlinger, N., Schwanninger, M., Hinterstoisser, B., and Jeronimidis, G. (2004). "Using a water-soluble melanine-formaldehyde resin to improve the hardness of Norway spruce wood," Journal of Applied Polymer Science 93(4), 1900-1907. DOI: 10.1002/app.20653

Glass, S. V., and Zelinka, S. L. (2010). "Moisture relations and physical properties of wood," in: Wood Handbook: Wood as an Engineering Material (FPL-GTR-190), R. J. Ross (ed.), U.S. Department of Agriculture, Forest Service, Forest Products Laboratory, Madison, WI, USA.

Goodell, B. (2003). "Brown-rot fungal degradation of wood: Our evolving view," in: Wood Deterioration and Preservation: Advances in Our Changing World, B. Goodell, D. D. Nicholas, and T. P. Schultz (eds.), American Chemical Society, Washington, D.C., USA, pp. 97-118. DOI: 10.1021/bk-2003-0845.ch006

Haloni, A., and Vergnaud, J. M. (1997). "Study of the release in water of chemicals used for wood preservation. Effect of wood dimensions," Wood Science and Technology 31(1), 51-62. DOI: 10.1007/BF00705700 
Havimo, M., Rikala, J., Sirviö, J., and Sipi, M. (2008). "Distributions of tracheid crosssectional dimensions in different parts of Norway spruce stems," Silva Fennica 42(1), 89-99. DOI: $10.14214 /$ sf.266

Hill, C. A. S. (2006). Wood Modification: Chemical, Thermal and Other Processes, John Wiley \& Sons, Ltd., Chichester, UK. DOI: 10.1002/0470021748

Ibach, R. E. (1999). "Wood preservation," in: Wood Handbook: Wood as an Engineering Material (FPL-GTR-113), U.S. Department of Agriculture, Forest Service, Forest Products Laboratory, Madison, WI, USA.

Islam, M. N., Ando, K., Yamauchi, H., Kobayashi, Y., and Hattori, N. (2008). "Comparative study between full cell and passive impregnation method of wood preservation for laser incised Douglas fir lumber," Wood Science and Technology 42(4), 343-350. DOI: 10.1007/s00226-007-0168-z

Jiang, X. (2008). Amine Oxides for Use in Wood Protection: III. Penetration Aids for Wood (IRG/WP 08-30461), International Research Group on Wood Protection, Stockholm, Sweden.

Kjellow, A. W., Henriksen, O., Sørensen, J. C., Johannsen, M., and Felby, C. (2010). "Partitioning of organic biocides between wood and supercritical carbon oxide," The Journal of Supercritical Fluids 52(1), 1-5. DOI: 10.1016/j.supflu.2009.12.005

Kocaefe, D., Huang, X., and Kocaefe, Y. (2015). "Dimensional stabilization of wood," Current Forestry Reports 1(3), 151-161. DOI: 10.1007/s40725-015-0017-5

Kukowski, K., Martinska, V., Sedgeman, C. A., Kuplic, P., Kozliak, E. I., Fisher, S., and Kubatova, A. (2017). "Fate of triazoles in softwoods upon environmental exposure," Chemosphere 184(1), 261-268. DOI: 10.1016/j.chemosphere.2017.05.168

Kukowski, K., Hatton, J., Kozliak, E. I., and Kubatova, A. (2018). "The extent of tebuconazole leaching from unpainted and painted softwood," Science of the Total Environment 633(1), 1379-1385. DOI: 10.1016/j.scitotenv.2018.03.274

Kukowski, K., Brianna, G., Fisher, S., and Kubatova, A. (2019). "Optimisation of electrospray ionisation for liquid chromatography time-of-flight analysis of preservatives in wood leachate matrix," Chromatographia 82(11), 1677-1685. DOI: 10.1007/s10337-019-03780-3

Kuroda, N., and Siau, J. F. (1988). "Evidence of nonlinear flow in softwoods from wood permeability measurements," Wood and Fiber Science 20(1), 162-169.

Laks, P. E. (2008). "Wood preservative fungicides and the American Wood Preservers' Association Use Category System," in: Development of Commercial Wood Preservatives: Efficacy, Environmental, and Health Issues, T. P. Schultz, H. Militz, M. H. Freeman, B. Goodell, and D. D. Nicholas (eds.), American Chemical Society, Washington, D.C., USA, pp. 228-240. DOI: 10.1021/bk-2008-0982.ch013

Lebow, S., Cooper, P., and Lebow, P. (2004). "Variability in evaluating environmental impacts of treated wood," in: Proceeding of Environmental Impacts of Preservativetreated Wood (FPL-RP-620), U.S. Department of Agriculture, Forest Service, Forest Products Laboratory, Madison, WI, USA.

Leightley, L. E. (2003). "Protection of wood using combinations of biocides," in: Wood Deterioration and Preservation: Advances in Our Changing World, B. Goodell, D. D. Nicholas, and T. P. Schultz (eds.), American Chemical Society, Washington, D.C., USA, pp. 390-398. DOI: 10.1021/bk-2003-0845.ch024

Li, H., Chen, F., Cheng, H., Deng, J., Wang, G., and Sun, F. (2014). "Large-span bamboo fiber-based composites, Part 1: A prediction model based on the Lucas-Washburn 
equation describing the resin content of bamboo fiber impregnated with different PVAC/PF concentrations," BioResources 9(4), 6408-6419.

Matsumura, J., Booker, R. E., Donaldson, L. A., and Ridoutt, B. G. (1998).

"Impregnation of radiata pine wood by vacuum treatment: Identification of flow paths using fluorescent dye and confocal microscopy," IAWA Journal 19(1), 25-33. DOI: $10.1163 / 22941932-90000649$

McQuire, A. J. (1970). Radial Permeability of Timber, Ph.D. Thesis, University of Leeds, Leeds, UK.

Messner, K., Bruce, A., and Bongers, H. P. M. (2003). "Treatability of refractory wood species after fungal pre-treatment," in: Proceedings - The First European Conference on Wood Modification 2003, April 3-4, Ghent, Belgium, pp. 389-401.

Miyauchi, T., Mori, M., and Ito, K. (2005). "Application of solid-phase extraction to quantitatively determine cyproconazole and tebuconazole in treated wood using liquid chromatography with UV detection," Journal of Chromatography A 1063(1-2), 137-141. DOI: 10.1016/j.chroma.2004.11.086

Morris, P. I., Grace, J. K., Yoshimura, T, and Tsunoda, K. (2014). “An international termite field test of wood treated with insecticides in a buffered amine oxide carrier," Forest Products Journal 64(5-6), 156-160. DOI: 10.13073/FPJ-D-13-00095

Olsson, T., Megnis, M., Varna, J., and Lindberg, H. (2001). "Study of the transverse liquid flow paths in pine and spruce using scanning electron microscopy," Journal of Wood Science 47(4), 282-288. DOI: 10.1007/BF00766714

Oraedd, G., Lindblom, G., Johansson, L. B. A., and Wikander, G. (1992). "Effect of hydrophobic molecules on N,N-dimethyldodecylamine oxide micelles in water," Journal of Physical Chemistry 96(12), 5170-5174. DOI: 10.1021/j100191a077

Panshin, A. J., de Zeeuw, C., and Brown, H. P. (1964). Textbook of Wood Technology. Vol. 1, Structure, Identification, Uses, and Properties of the Commercial Woods of the United States, McGraw-Hill, New York, NY, USA.

Pepin, S., Blanchet, P., and Landry, V. (2019). "Performances of white pine and white spruce treated with organic fungicides using an aqueous buffered amine oxide preservation system," BioResources 14(1), 264-288. DOI: 10.15376/biores.14.1.264288

Petty, J. A., and Puritch, G. S. (1970). "The effect of drying on the structure and permeability of the wood of Abies grandis," Wood Science and Technology 4(2), 140154. DOI: $10.1007 / \mathrm{BF} 00365299$

Reinprecht, L. (2016). Wood Deterioration, Protection and Maintenance, John Wiley \& Sons, Ltd., Chichester, UK. DOI: 10.1002/9781119106500

Rhatigan, R., Freitag, C., El-Kasmi, S., and Morell, J. J. (2004). "Preservative treatment of Scots pine and Norway spruce," Forest Products Journal 54(10), 91-94.

Ross, A. S. (2008). "Organic preservative systems for the protection of wood windows and doors," in: Development of Commercial Wood Preservatives: Efficacy, Environmental, and Health Issues, T. P. Schultz, H. Militz, M. H. Freeman, B. Goodell, and D. D. Nicholas (eds.), American Chemical Society, Washington, D.C., USA, pp. 470-479. DOI: 10.1021/bk-2008-0982.ch028

Ross, A. S., and Cutler, K. A. (2015). "Method of employing enhanced penetration of wood preservatives to protect wood and a related solution," U. S. Patent No. 9125399B2.

Rydholm, S. A. (1967). Pulping Processes, Interscience Publishers, New York, NY, USA. 
Sanderson, H., Counts, J. L., Stanton, K. L., and Sedlak, R. I. (2006). "Exposure and prioritization - Human screening data and methods for high production volume chemicals in consumer products: Amine oxides a case study," Risk Analysis 26(6), 1637-1657. DOI: 10.1111/j.1539-6924.2006.00829.x

Sanderson, H., Tibazarwa, C., Greggs, W., Versteeg, D. J., Kasai, Y., Stanton, K., and Sedlak, R. I. (2009). "High production volume chemical amine oxides $\left[\mathrm{C}_{8}-\mathrm{C}_{20}\right]$ category environmental risk assessment," Risk Analysis 29(6), 857- 867. DOI: 10.1111/j.1539-6924.2009.01208.x

Scholz, G., Krause, A., and Militz, H. (2010). "Exploratory study on the impregnation of Scots pine (Pinus sylvestris L.) and European beech (Fagus sylvatica L.) with different hot melting waxes," Wood Science and Technology 44(3), 379-388. DOI: 10.1007/s00226-010-0353-3

Schubert, M., Volkmer, T., Lehringer, C., and Schwarze, F. W. M. R. (2011). "Resistance of bioincised wood treated with wood preservatives to blue-stain and wood-decay fungi," International Biodeterioration and Biodegradation 65(1), 108-115. DOI: 10.1016/j.ibiod.2010.10.003

Schultz, T. P., and Nicholas, D. D. (2003). "A brief overview of non-arsenical wood preservative systems," in: Wood Deterioration and Preservation: Advances in Our Changing World, B. Goodell, D. D. Nicholas, and T. P. Schultz (eds.), American Chemical Society, Washington, D.C., USA, pp. 420-432. DOI: 10.1021/bk-20030845.ch026

Siau, J. F. (1984). Transport Processes in Wood, Springer-Verlag, Berlin, Germany. DOI: 10.1007/978-3-642-69213-0

Siau, J. F. (1995). Wood: Influence of Moisture on Physical Properties, Department of Wood Science and Forest Products, Virginia Polytechnic Institute and State University, Blacksburg, VA, USA.

Sjöström, E. (1993). Wood Chemistry: Fundamentals and Applications, $2^{\text {nd }}$ Edition, Academic Press, Inc., San Diego, CA, USA. DOI: 10.1016/C2009-0-03289-9

Sjöström, E., and Westermark, U. (1999). "Chemical composition of wood and pulps: Basic constituents and their distribution," in: Analytical Methods in Wood Chemistry, Pulping, and Papermaking, E. Sjöström and R. Alén (eds.), Springer-Verlag, Berlin, Germany, pp. 1-19. DOI: 10.1007/978-3-662-03898-7_1

Stamm, A. J. (1967). "Movement of fluids in wood - Part I: Flow of fluids in wood," Wood Science and Technology 1(2), 122-141. DOI: 10.1007/BF00353384

Stevanovic, T. (2016). "Chemical composition and properties of wood," in: Lignocellulosic Fibers and Wood Handbook: Renewable Materials for Today's Environment, N. Belgacem and A. Pizzi (eds.), Scrivener Publishing, Beverly, MA, USA. DOI: 10.1002/9781118773727.ch3

Torgovnikov, G., and Vinden, P. (2010). "Microwave wood modification technology and its applications," Forest Products Journal 60(2), 173-182. DOI: 10.13073/00157473-60.2.173

Tseng, C.-I., and Walker, L. E. (2000). “Azole/amine oxide wood preservatives,” WO Patent No. 2000071314A1.

Tseng, C.-I., Walker, L. E., and Kempinska, C. (2002). "Compositions comprising a boron compound and an amine oxide," WO Patent No. 2002001958A2.

Usta, I. (2005). "A review of the configuration of bordered pits to stimulate the fluid flow," Maderas. Ciencia y Tecnología 7(2), 121-132. DOI: 10.4067/S0718221X2005000200006 
van Meel, P. A., Erich, S. J. F., Huinink, H. P., Kopinga, K., de Jong, J., and Adan, O. C. G. (2011). "Moisture transport in coated wood," Progress in Organic Coatings 72(4), 686-694. DOI: 10.1016/j.porgcoat.2011.07.011

Volkmer, T., Landmesser, H., Genoud, A., and Schwarze, F. W. M. R. (2010). "Penetration of 3-iodo-2-propynyl butylcarbamate (IPBC) in coniferous wood pretreated with Physisporinus vitreus," Journal of Coatings Technology and Research 7(6), 721-726. DOI: 10.1007/s11998-010-9259-0

Voulgaridis, E., Adamopoulos, S., Karastergiou, S., Passialis, C., Koutsianitis, D., Kortsalioudakis, N., Petrakis, P., and Moustaizis, S. (2015). "Effects of laser drilling on mechanical properties and impregnability of fir and spruce wood," Innovation in Woodworking Industry and Engineering Design 1(4), 14-22.

Walker, L. E., and Shen, S. (2002). "Methods for enhancing penetration of wood preservatives," U. S. Patent No. 20020061366A1.

Wan, H. and Kim, M. G. (2008). "Distribution of phenol-formaldehyde resin in impregnated southern pine and effects on stabilization," Wood and Fiber Science 40(2), 181-189.

Wang, C., and Piao, C. (2011). "From hydrophilicity to hydrophobicity: A critical review-Part II: Hydrophobic conversion," Wood and Fiber Science 43(1), 41-56.

Ward, H. A., and Scott, C. (2009). "Method of protecting wood through enhanced penetration of wood preservatives and a related solution," U. S. Patent No. 20090143334A1.

Wiedenhoeft, A. (2010). "Structure and Function of Wood," in: Wood Handbook: Wood as an Engineering Material (FPL-GTR-190), R. J. Ross (ed.), U.S. Department of Agriculture, Forest Service, Forest Products Laboratory, Madison, WI, USA.

Woo, C. S.-M. (2010). Efficacy of Tebuconazole and DDAC in Shell-treated Wood, Master's Thesis, The University of British Columbia, Vancouver, BC, Canada.

Yuan, J., Hu, Y., Li, L., and Cheng, F. (2013). "The mechanical strength change of wood modified with DMDHEU," BioResources 8(1), 1076-1088. DOI:

10.15376/biores.8.1.1076-1088

Article submitted: October 9, 2019; Peer review completed: November 17, 2019; Revised version received: December 16, 2019; Accepted: December 17, 2019; Published:

December 18, 2019.

DOI: 10.15376/biores.15.1.1026-1049 